\title{
AL-IQTISHADIYAH
}

Jurnal Ekonomi Syariah dan Hukum Ekonomi Syariah

E-ISSN: 2621-0274; P-ISSN: 2442-2282

Volume 7, Nomor 2, Desember 2021

\section{Analisis Kesehatan Laporan Keuangan Bank Muamalat Indonesia Tahun 2016-2020 dengan Menggunakan Metode RGEC}

\section{Nabilatul Mumtazah Putri Husaein ${ }^{1} \&$ Muhammad Iqbal Surya Pratikto}

1 Fakultas Ekonomi dan Bisnis Islam, Universitas Islam Negeri Sunan Ampel Surabaya, Indonesia. E-mail: nabilamumtazah5@gmail.com

2 Fakultas Ekonomi dan Bisnis Islam, Universitas Islam Negeri Sunan Ampel Surabaya, Indonesia. E-mail: m.iqbal@uinsby.ac.id

\section{ARTICLE INFO}

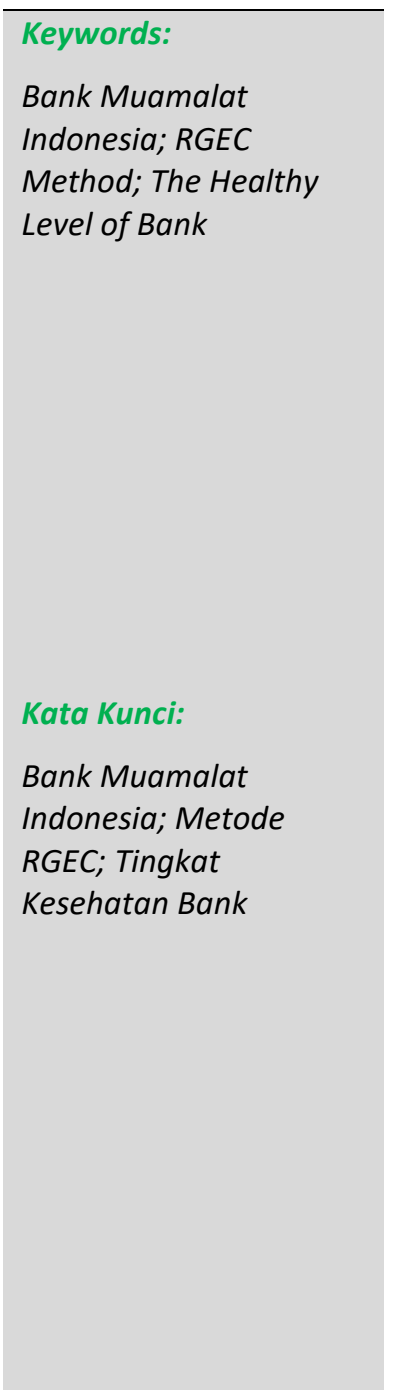

\section{ABSTRACT}

This study aims to determine the health level of Bank Muamalat Indonesia in 2016-2020 using the RGEC method which consists of four components namely Risk Profile, GCG (Good Corporate Governance), Earnings, and Capital. The results of the research about the health level of Bank Muamalat Indonesia in 2016-2020 showed that the NPF ratio is good except in 2019 which was considered quite good because it was in quiet health condition. Then the bank's FDR ratio showed good results except in 2016 because the result of the analysist was in quite good category. For the PDN ratio, the bank showed quite good. Meanwhile the ratio of ROA, ROE, and BOPO are considered less good because all of them are in the unhealthy category. Meanwhile, for the NI ratio in 2016-2018 is good, for 2019 is less good, and for 2020 is quite good. While in the CAR ratio, the bank is in the very healthy category so that it can be said to be very good condition.

\section{ABSTRAK}

Penelitian ini bertujuan untuk mengetahui tingkat kesehatan pada Bank Muamalat Indonesia periode tahun 2016-2020 dengan menggunakan metode RGEC yang meliputi empat komponen yakni Risk Profile (Profil Risiko), GCG (Good Corporate Governance), Earnings (Rentabilitas), dan Capital (Modal). Hasil penelitian selama periode 2016-2020 tercatat bahwa pada rasio NPF bank menunjukkan hasil yang baik kecuali untuk tahun 2019 yang termasuk cukup baik karena termasuk dalam kategori yang cukup sehat. Kemudian pada rasio FDR bank menunjukkan hasil yang baik kecuali di tahun 2016 karena hasil analisisnya berada dalam kategori cukup sehat. Untuk rasio PDN, bank dikatakan cukup baik. Sedangkan pada rasio ROA, ROE, dan BOPO kurang baik karena semuanya berada dalam kategori kurang sehat. Sementara itu, untuk rasio NI di tahun 2016-2018 bank dikatakan baik, tahun 2019 kurang baik, dan tahun 2020 cukup baik. Sedangkan pada rasio CAR, bank berada dalam kategori sangat sehat sehingga dapat dikatakan sangat baik. 


\section{Pendahuluan}

Perekonomian menjadi salah satu aspek kehidupan bermasyarakat yang banyak dibahas dalam agama Islam. Melalui Al-Quran, hadits, sunnah, ijma' para ulama, dan sumber-sumber shahih lainnya, ekonomi dibahas untuk dijadikan pedoman dan petunjuk bagi umat manusia dalam menjalankan praktik perekonomian sehari-harinya. Dalam penerapannya, saat ini di Indonesia telah banyak berdiri berbagai macam lembaga keuangan yang berbasis pada ketentuan syariah misalnya seperti, perbankan syariah, koperasi syariah, BMT (Baitul Maal Wat tamwil), pegadaian syariah, dan berbagai lembaga lainnya.

Diantara banyaknya lembaga keuangan syariah yang saat ini semakin berkembang, masyarakat Indonesia paling banyak dijumpai menggunakan layanan perbankan syariah sebagai lembaga keuangan syariah yang membantu mengelola dan menyalurkan dana-dana mereka. Saat ini perbankan syariah sendiri di Indonesia telah berkembang lebih luas lagi dengan mulai bermunculannya bank-bank umum/konvensional yang melebarkan sayapnya di ranah perbankan syariah.

Gagasan pendirian lembaga perbankan berbasis Syariah di Indonesia sebetulnya telah terjadi semenjak tahun 1970-an yang saat itu dibahas di acara seminar nasional Hubungan Indonesia-Timur Tengah tahun 1974 dan pada kegiatan seminar internasional yang diadakan oleh Lembaga Studi llmu-ilmu Kemasyarakatan (LSIK) dan Yayasan Bhineka Tunggal Ika. Akan tetapi gagasan tersebut hanya berhenti disitu saja karena beberapa alasan yang cukup meragukan bagi para petinggi negara. Beberapa alasan yang dimaksud adalah belum adanya peraturan resmi dari undang-undang perbankan yang mengatur tentang adanya system bagi hasil, sistem syariah yang dianggap terlalu ideologis dan terkesan seperti negara islam, serta adanya kebingungan akan siapa yang akan menaru modal untuk keberlangsungan lembaga ini. ${ }^{1}$ Setelah melalui masa tunggu yang cukup lama, akhirnya pada tahun 1990 tepatnya saat Musyawarah Nasional IV Majelis Ulama Indonesia, ide pendirian perbankan syariah ini dikupas lebih dalam hingga akhirnya membentuk kelompok kerja untuk menyusun dan mengatur pembentukan bank syariah di Indonesia.

Dari hasil pembahasan serta pembentukan kelompok kerja tersebut akhirnya didirikanlah lembaga perbankan syariah pertama di Inonesia yang bernama PT. Bank Muamalat Indonesia (BMI). Seiring mulainya aktivitas PT. Bank Muamalat Indonesia pada saat itu, dibuatlah peraturan perundang-undangan tentang perbankan yang membahas mengenai perbankan syariah yakni pada Undang-undang No. 7 Tahun 1992 dimana pada pasal 13 ayat (c) disebutkan bahwa Bank Perkreditan Rakyat (BPR) menyediakan pembiayaan bagi nasabah berdasarkan prinsip bagi hasil sesuai dengan ketentuan yang telah ditetapkan oleh pemerintah, namun dapat dikatakan masih

\footnotetext{
${ }^{1}$ Nofinawati Nofinawati, "Perkembangan Perbankan Syariah Di Indonesia," JURIS (Jurnal IImiah Syariah) 14, no. 2 (2016): 168, https://doi.org/10.31958/juris.v14i2.305.
} 
terbatas. ${ }^{2}$ Enam tahun setelahnya, Undang-undang Nomor 10 Tahun 1998 lahir sebagai pengganti UU No.7 Tahun $1992 .^{3}$ Dengan begitu, sejak saat itu kedudukan Bank Muamalat Indonesia (BMI) sebagai lembaga perbankan syariah pertama di Indonesia menjadi lebih kuat karena adanya dukungan dari konstitusi tersebut dan memiliki kesempatan yang bagus untuk terus berkembang. ${ }^{4}$

Kiprah Bank Muamalat di Indonesia telah melalui berbagai fase bahkan bisa dibilang bank pernah mengalami titik terendah kerugian selama masa pendiriannya. Pada saat terjadinya krisis moneter di tahun 1998, BMI mengalami kerugian sebesar Rp. 105 miliar. Hal ini dapat terjadi dikarenakan besarnya gejolak perekonomian Indonesia pada masa itu. Bahkan nilai ekuitas bank yang tercatat bernilai jauh jika dibandingkan dengan modal awal saat bank didirikan. Diperkirakan nilai ekuitas pada saat itu hanya mencapai sekitar Rp. 39 miliar. Melihat kilas balik perjalanan Bank Muamalat Indonesia yang tidak mudah tetapi hingga saat ini masih terus berdiri dan membantu masyarakat dalam melakukan pengelolaan dana, patut diakui bahwa PT. Bank Muamalat Indonesia Tbk sangat konsisten dalam membantu dan mewujudkan kegiatan perekonomian umat dengan berbasis syariah. Namun konsisten dalam mengemban tugas dan tujuan awalnya tidak membuat Bank Muamalat Indonesia terbebas begitu saja dari jerat kerugian. Keuntungan yang menurun sangat drastis juga pernah dialami oleh Bank Muamalat pada pertengahan tahun 2019 sehingga diputuskan untuk sementara Bank Muamalat Indonesia berhenti melayani pembiayaan nasabah. ${ }^{5}$

Peristiwa yang sempat dialami oleh Bank Muamalat Indonesia ini merupakan sebuah gambaran ketika kesehatan keuangan dalam perbankan mengalami ketidakstabilan. Apabila sebuah lembaga perbankan tidak stabil dalam menjaga kesehatan keuangannya, maka kegiatan operasional bank akan susah untuk berjalan dengan semestinya. Oleh karenanya, sangat dibutuhkan pengelolaan yang baik serta perhatian ekstra dari pihak bank dalam menjalankan tugas-tugasnya sehingga kesehatan bank tetap terjaga dengan stabil.

Setiap lembaga perbankan pasti memiliki berbagai macam risiko, salah satunya merupakan risiko pembiayaan yang dapat terjadi karena kegagalan salah satu pihak

\footnotetext{
${ }^{2}$ Yudhistira Ardana and W Wulandari, "Tingkat Suku Bunga, Kinerja Keuangan, Dan Bagi Hasil Deposito Pada Perbankan Syariah," Esensi: Jurnal Bisnis Dan Manajemen 8, no. 2 (2018): 177-86, https://doi.org/10.15408/ess.v8i2.8392.

${ }^{3}$ Andrew Shandy Utama, "Perkembangan Perbankan Syariah Di Indonesia," UNES Law Review 2, no. 3 (2020): 290-98, https://doi.org/10.31933/unesrev.v2i3.121.

${ }^{4}$ Agus Marimin and Abdul Haris Romdhoni, “Perkembangan Bank Syariah Di Indonesia," Jurnal Ilmiah Ekonomi Islam 1, no. 02 (2017): 75-87, https://doi.org/10.29040/jiei.v1i02.30.

${ }^{5}$ Muhammad Iqbal Surya Pratikto, Clarissa Belinda Fabrela, and Maziyah Mazza Basya, “Analisis Kesehatan Laporan Keuangan Pada PT Bank Muamalat Indonesia Tbk Dengan Menggunakan Metode Camel Tahun 2015-2019," OECONOMICUS Journal of Economics 5, no. 2 (2021): 75-85, https://doi.org/10.15642/oje.2021.5.2.75-85.
} 
dalam menjalankan kewajibannya. ${ }^{6}$ Analisis laporan keuangan pada bank salah satunya bertujuan untuk mengetahui langkah perbaikan yang perlu direncanakan bank di masa depan. ${ }^{7}$ Untuk menjaga kestabilan keuangan pada lembaga perbankan dapat dilakukan dengan menganalisis kesehatan keuangan pada setiap tahun atau periodenya. Analisis ini dapat dilakukan dengan dua cara yang dinamakan metode CAMEL dan metode RGEC. Metode CAMEL berisikan lima komponen yakni Capital (modal), Asset (Aktiva), Management (Manajemen), Earning (Rentabilitas), dan Liquidity (Likuiditas). Sedangkan metode RGEC berisi Risk Profile (Profil Resiko), GCG (Good Corporate Governance), Earning (Rentabilitas), dan Capital (Modal).

Seperti pada jurnal karya Muhammad Iqbal Surya Pratikto, Clarissa Belinda Fabrela, dan Maziyah Mazza Basya tahun 2021 yang berjudul "Analisis Kesehatan Laporan Keuangan Pada PT. Bank Muamalat Indonesia Tbk dengan Menggunakan Metode Camel Tahun 2015-2019" dimana pada penelitian tersebut dijelaskan bahwa kesehatan Bank Muamalat Indonesia pada tahun 2015-2019 dianggap baik menurut rasio CAR, NPF, dan NI. Berdasarkan rasio PDN dan FDR dianggap cukup baik, dan bagi rasio $B O P O$ kesehatan bank terhitung kurang baik.

Keadaan dimana Bank Muamalat Indonesia memiliki rata-rata tingkat kesehatan yang sehat adalah terjadi pada tahun 2010 hingga 2012 dimana tercatat dalam penelitian yang telah dilakukan oleh Rafki Rachmat Akbar dan Pandoyo ${ }^{8}$ di tahun 2020 dengan judul penelitian "Analisis Tingkat Kesehatan Bank Dengan Menggunakan Metode Camel Pada PT Bank Muamalat Indonesia Tbk", dimana hasilnya menunjukkan bahwa tingkat kesehatan Bank Muamalat Indonesia di tahun 2010-2012 berada dalam kategori sehat secara keseluruhan.

Selain menggunakan metode CAMEL tingkat kesehatan lembaga perbankan dapat juga diukur dengan metode RGEC, sebagaimana penelitian yang telah dilakukan oleh Zeze Zakaria Hamzah dan Dewi Anggraini ${ }^{9}$ pada tahun 2019 dengan judul "Analisis Tingkat Kesehatan Bank Pada PT Bank Muamalat Indonesia Tbk Dengan Menggunakan Metode RGEC (Risk Profile, Good Corporate Governanve, Earnings, \& Capital) Periode 2013-2017". Hasil penelitian tersebut menunjukkan bahwa di tahun 2013-2017 tingkat kesehatan Bank Muamalat Indonesia melalui metode RGEC secara keseluruhan adalah berada dalam kategori yang kurang sehat. Hal ini dapat diketahui

\footnotetext{
${ }^{6}$ Bagya Agung Prabowo and Jasri Bin Jamal, "Peranan Dewan Pengawas Syariah Terhadap Praktik Kepatuhan Syariah Dalam Perbankan Syariah Di Indonesia," Jurnal Hukum IUS QUIA IUSTUM 24, no. 1 (2017): 113-29, https://doi.org/10.20885/iustum.vol24.iss1.art6.

${ }^{7}$ Kasmir, Analisis Laporan Keuangan (Depok: PT. RajaGrafindo Persada, 2019).

${ }^{8}$ Rafki Rachmat Akbar and Pandoyo, “Analisis Tingkat Kesehatan Bank Dengan Menggunakan Metode Camel Pada PT. Bank Mualamat Indonesia Tbk.," Bisnis Administrasi 5, no. September (2016): 45.

${ }^{9}$ Zeze Zakaria Hamzah and Dewi Anggraini, “ANALISIS TINGKAT KESEHATAN BANK PADA PT BANK MUAMALAT INDONESIA, TbK DENGAN MENGGUNAKAN METODE RGEC (RISK PROFILE, GOOD CORPORATE GOVERNANCE, EARNING \& CAPITAL) PERIODE 2013 - 2017," Economicus 13, no. 1 (2020): 46-56, https://doi.org/10.47860/economicus.v13i1.164.
} 
dari masing-masing komponen yang beberapa kali menduduki kategori cukup dan kurang sehat.

Sementara itu, pada penelitian kali ini peneliti akan menganalisis tingkat kesehatan Bank Muamalat Indonesia dengan menggunakan metode RGEC pada periode terbaru 5 (lima) tahun terakhir yakni tahun 2016 sampai 2020.

\section{Landasan Teori}

\section{Kesehatan Bank}

Kesehatan Bank ialah suatu kompetensi bagi setiap lembaga perbankan dalam mengelola akivitas dan operasional perbankan secara normal, kewajiban bank bisa dilaksanakan dengan baik dan benar serta dilakukan sesuai cara-cara yang sinkron dengan peraturan perbankan yang berlaku. ${ }^{10}$

Dalam menjaga kesehatannya, bank perlu mengetahui level kesehatan bank dengan melakukan analisis kesehatan pada beberapa komponen yang diperlukan dimana komponen tersebut adalah komponen yang memiliki pengaruh besar terhadap kondisi keuangan suatu bank. Dalam menilai kategori kesehatan bank dapat digolongkan menjadi 4 (empat) jenis kategori yakni sehat, cukup sehat, kurang sehat, dan tidak sehat. ${ }^{11}$ Sebelum menilai kategori kesehatan yang sesuai dengan kondisi bank, terdapat penentuan peringkat komposit yang nantinya digunakan sebagai pengukur tingkat kesehatan untuk mengetahui manakah kategori kesehatan yang sesuai. Peringkat komposit ini telah ditentukan dalam PBI 13/1/PBI/2011 tentang Kesehatan Bank. ${ }^{12}$ Tujuan penjagaan kesehatan pada setiap bank adalah untuk mengetahui baik atau tidaknya kinerja pada suatu bank dalam beberapa tahun atau periode. Penentuan tingkat kesehatan bank yang diperoleh melalui analisis kesehatan bank pun dapat mendukung bank untuk merancang strategi baru bagi keberlangsungan operasional di masa depan.

Bank yang memiliki tingkat kesehatan yang baik tidak hanya berdampak pada kondisi kinerja bank yang bagus secara keseluruhan namun juga berpengaruh terhadap kepecayaan, loyalitas, dan jumlah nasabah. ${ }^{13} \mathrm{Hal}$ ini sangat bagus bagi bank karena kepercayaan dan loyalitas nasabah menjadi penunjang yang sangat

\footnotetext{
${ }^{10}$ Andrianto and M. Anang Firmansyah, Manajemen Bank Syariah (Implementasi Teori Dan Praktek), ed. Qiara Media, CV. Penerbit Qiara Media (CV. Penerbit Qiara Media, 2019).

${ }^{11}$ Nopita Sari, “Analisis Tingkat Kesehatan Bank Dengan Menggunakan Metode Camel Pada PT. BNI Syariah Periode Triwulan Tahun 2015-2017," Islamic Banking : Jurnal Pemikiran Dan Pengembangan Perbankan Syariah 4, no. 1 (2018): 23-32, https://doi.org/10.36908/isbank.v4i1.52.

${ }^{12}$ Anik Anik and Suhesti Ningsih, "Analisis Tingkat Kesehatan Bank Mandiri Syariah Dengan Metode Risk Profile, Good Corporate Governace, Earnings and Capital," Jurnal IImiah Ekonomi Islam 6, no. 3 (2020): 724, https://doi.org/10.29040/jiei.v6i3.1466.

13 Nano Suyatna dan Ayi Mi'razul Mu'minin, “Analisis Tingkat Kesehatan Bank Dan Dampaknya Terhadap Peningkatan Jumlah Nasabah," Jurnal Maps (Manajemen Perbankan Syariah) 5, no. 1 (2021): 40-45.
} 
penting untuk keberhasilan bank di masa depan.

\section{Metode RGEC}

Metode RGEC merupakan salah satu metode yang dapat digunakan ketika melakukan analisis kesehatan laporan keuangan pada lembaga perbankan. Terdapat metode lain sebelum metode RGEC berkembang yakni metode CAMELS yang kemudian dikembangkan menjadi suatu bentuk metode baru bernama Metode RGEC. ${ }^{14}$ Metode RGEC terdiri dari 4 (empat) komponen yakni Risk Profile (Profil Risiko), GCG (Good Corporate Governance), Earning (Rentabilitas), dan Capital (Modal).

\section{Risk Profile (Profil Risiko)}

Risk Profile merupakan seluruh risiko yang dapat terjadi akibat adanya kegiatan operasional perbankan. Menurut aturan yang dikeluarkan oleh Bank Indonesia Nomor 13/1/PBI/2011 tentang Penilaian Tingkat Kesehatan Bank Umum menjelaskan bahwa pada risk profile mencakup delapan unsur risiko yaitu risiko kredit, risiko pasar, risiko likuiditas, risiko operasional, risiko hukum, risiko stratejik, risiko kepatuhan, dan risiko reputasi. ${ }^{15}$ Penentuan risk profile dapat dilakukan dengan melakukan perhitungan untuk mencari NPF (Non Performing Finance) serta FDR (Financing to Deposit Ratio).

Rumus NPF (Non Performing Finance):

$$
N P F=\frac{\text { Pembiayaan Bermasalah }}{\text { Total Kredit }} \times 100 \%
$$

Tabel 1. Klasifikasi Peringkat NPF

\begin{tabular}{ccc}
\hline Urutan & Nilai Komposit & Kategori \\
\hline 1 & NPF $\leq 2 \%$ & Sangat Sehat \\
\hline 2 & $2 \% \leq \mathrm{NPF}<5 \%$ & Sehat \\
\hline 3 & $5 \% \leq \mathrm{NPF}<8 \%$ & Cukup Sehat \\
\hline 4 & $8 \% \leq \mathrm{NPF}<12 \%$ & Kurang Sehat \\
\hline 5 & $\mathrm{NPF} \geq 12 \%$ & Tidak Sehat
\end{tabular}

\footnotetext{
${ }^{14}$ Rolia Wahasusmiah and Khoiriyyah Rahma Watie, "Metode RGEC : Penilaian Tingkat Kesehatan," IFinance 04, no. 02 (2018): 170-84.

${ }^{15}$ Muhammad Iqbal Surya Pratikto and Mohammad Khoiruzi Afiq, “Analisis Tingkat Kesehatan Bank Dan Potensi Financial Distress Menggunakan Metode Rgec Dan Zmijewski Pada Bank Bni Syariah Tahun 2015-2019," Jurnal Ekonomi Syariah Teori Dan Terapan 8, no. 5 (2021): 570, https://doi.org/10.20473/vol8iss20215pp570-581.
} 
Rumus FDR (Financing to Deposit Ratio):

$$
F D R=\frac{\text { Total Pembiayaan }}{\text { Total Dana Pihak Ketiga (DPK) }} \times 100 \%
$$

Tabel 2. Klasifikasi Peringkat FDR

\begin{tabular}{ccc}
\hline Urutan & Nilai Komposit & Kategori \\
\hline 1 & FDR $\leq 75 \%$ & Sangat Sehat \\
\hline 2 & $75 \%<$ FDR $\leq 85 \%$ & Sehat \\
\hline 3 & $85 \%<$ FDR $\leq 100 \%$ & Cukup Sehat \\
\hline 4 & $100 \%<$ FDR $\leq 120 \%$ & Kurang Sehat \\
\hline 5 & FDR $>120 \%$ & Tidak Sehat \\
\hline
\end{tabular}

\section{GCG (Good Corporate Governance)}

Berdasarkan Bank Dunia (World Bank), GCG ialah suatu bentuk kelompok peraturan atau kaidah-kaidah hukum yang harus dipenuhi oleh lembaga perbankan serta dapat meningkatkan kinerja sumber perusahaan supaya mampu berjalan dengan efisien dan dapat mewujudkan nilai ekonomi jangka panjang yang berkelanjutan baik bagi pemilik saham maupun seluruh pelanggan dan masyarakat. ${ }^{16}$ GCG (Good Corporate Governance) wajb beralaskan pada lima prinsip dasar diantaranya yakni transparansi, akuntabilitas, tanggung jawab, independensi, serta kewajaran. Perhitungan aspek GCG pada metode RGEC dihitung melalui Posisi Devisa Netto (PDN). ${ }^{17}$

$$
\begin{gathered}
\text { Rumus PDN (Posisi Devisa Netto): } \\
\text { PDN }=\frac{\text { Selisih Aset dan Liabilitas Valas }}{\text { Total Modal }} \times 100 \%
\end{gathered}
$$

\begin{tabular}{|c|c|c|}
\hline Urutan & Nilai Komposit & Kategori \\
\hline 1 & Tidak ada pelanggaran rasio PDN & Sangat Sehat \\
\hline 2 & Pernah melakukan pelanggaran namun sudah diselesaikan & Sehat \\
\hline 3 & $0 \%<\mathrm{PDN} \leq 10 \%$ & Cukup Sehat \\
\hline
\end{tabular}

Tabel 3. Klasifikasi Peringkat PDN

\footnotetext{
${ }^{16}$ Wahasusmiah and Watie, "Metode RGEC : Penilaian Tingkat Kesehatan."

17 Muhammmad Iqbal Surya Pratikto, Ariza Qanita, and Rahma Ulfa Maghfiroh, "Analisis Tingkat Kesehatan Dan Potensi Financial Distress Dengan Metode RGEC Pada BNI Syariah Tahun 2014-2018," Jurnal El-Qist 9, no. 1 (2019): 87.
} 


\begin{tabular}{ccc}
\hline 4 & $10 \%<$ PDN $\leq 25 \%$ & Kurang Sehat \\
\hline 5 & PDN $>25 \%$ & Tidak Sehat \\
\hline
\end{tabular}

\section{Earnings (Rentabilitas)}

Earnings merupakan salah satu kriteria penting pada pengukuran tingkat kesehatan pada perbankan yang berhubungan dengan kapabilitas bank dalam memperoleh laba/keuntungan. ${ }^{18}$ Untuk melakukan pengukuran penilaian earnings dapat dilakukan dengan menghitung empat aspek yakni ROA (Return On Assets), ROE (Return On Equity), NI (Net Imbalan), dan BOPO (Biaya Operasional terhadap Pendapatan Operasional).

Rumus ROA (Return On Assets):

$$
\mathrm{ROA}=\frac{\text { Laba Sebelum Pajak }}{\text { Rata }- \text { rata Total Aset }} \times 100 \%
$$

Tabel 4. Klasifikasi Peringkat ROA

\begin{tabular}{|c|c|c|}
\hline Urutan & Nilai Komposit & Kategori \\
\hline 1 & $\mathrm{ROA} \geq 2 \%$ & Sangat Sehat \\
\hline 2 & $1,26 \% \leq \mathrm{ROA}<5 \%$ & Sehat \\
\hline 3 & $0,51 \% \leq \mathrm{ROA}<1,25 \%$ & Cukup Sehat \\
\hline 4 & $0 \% \leq \mathrm{ROA}<0,5 \%$ & Kurang Sehat \\
\hline 5 & ROA $<0 \%$ & Tidak Sehat \\
\hline \multicolumn{3}{|c|}{ Rumus ROE (Return On Equity): } \\
\hline \multicolumn{3}{|c|}{$\mathrm{ROE}=\frac{\text { Laba Setelah Pajak }}{\text { Rata }- \text { rata Total Modal }} \times 100 \%$} \\
\hline \multicolumn{3}{|c|}{ Tabel 5. Klasifikasi Peringkat ROE } \\
\hline Urutan & Nilai Komposit & Kategori \\
\hline 1 & ROE $\geq 20 \%$ & Sangat Sehat \\
\hline 2 & $12,51 \% \leq \mathrm{ROE}<20 \%$ & Sehat \\
\hline 3 & $5,01 \% \leq \mathrm{ROE}<12,5 \%$ & Cukup Sehat \\
\hline 4 & $0 \% \leq \mathrm{ROE}<5 \%$ & Kurang Sehat \\
\hline
\end{tabular}

${ }^{18}$ F. Prastyananta, M. Saifi, and M. NP, "ANALISIS PENGGUNAAN METODE RGEC (RISK PROFILE, GOOD CORPORATE GOVERNANCE, EARNING, CAPITAL) UNTUK MENGETAHUI TINGKAT KESEHATAN BANK (Studi Pada Bank Umum Yang Terdaftar Di BEl Periode 2012-2014)," Jurnal Administrasi Bisnis S1 Universitas Brawijaya 35, no. 2 (2016): 68-76. 


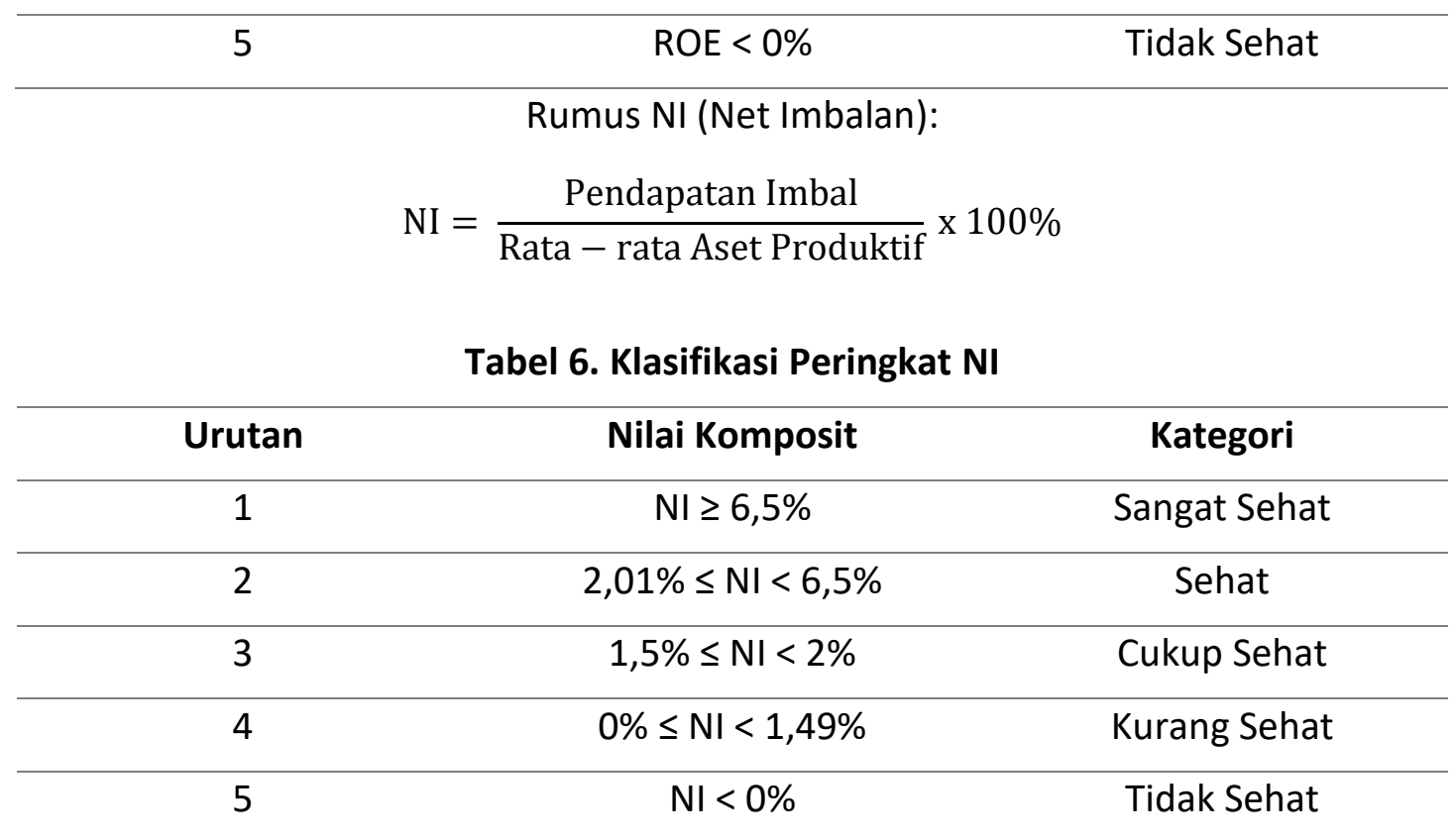

Rumus BOPO (Biaya Operasional terhadap Pendapatan Operasional):

$$
\text { BOPO }=\frac{\text { Biaya Operasional }}{\text { Pendapatan Operasional }} \times 100 \%
$$

Tabel 7. Klasifikasi Peringkat BOPO

\begin{tabular}{ccc}
\hline Urutan & Nilai Komposit & Kategori \\
\hline 1 & BOPO $<88 \%$ & Sangat Sehat \\
\hline 2 & $89 \%-93 \%$ & Sehat \\
\hline 3 & $94 \%-96 \%$ & Cukup Sehat \\
\hline 4 & $97 \%-100 \%$ & Kurang Sehat \\
\hline 5 & BOPO $>100 \%$ & Tidak Sehat \\
\hline
\end{tabular}

\section{Capital (Modal)}

Komponen ini merupakan salah satu faktor utama terjadinya aktivitas ekonomi pada lembaga perbankan. Pengukuran nilai modal tidak hanya digunakan untuk mengetahui kapasitas modal yang cukup bagi bank namun juga digunakan untuk mengukur pengelolaan modal secara keseluruhan. Bank harus menyiapkan modal yang besar seiring dengan tingginya risiko yang ada. ${ }^{19}$ Penilaian capital pada bank dapat diukur melalui perhitungan rasio CAR (Capital Adequacy Ratio). Baiknya rasio CAR menunjukkan bahwa bank dinilai cakap dalam mengatasi risiko pembiayaan

\footnotetext{
${ }^{19}$ Agita Putra Pramana and Irni Yunita, "Pengaruh Rasio-Rasio Risk-Based Bank Rating (Rbbr) Terhadap Peringkat Obligasi," Jurnal Manajemen Indonesia 15, no. 1 (2017): 65, https://doi.org/10.25124/jmi.v15i1.394.
} 
dengan keseluruhan modal yang dimiliki. ${ }^{20}$

Rumus CAR (Capital Adequacy Ratio):

$$
\mathrm{CAR}=\frac{\text { Modal }}{\text { Aset Tertimbang Menurut Risiko }} \times 100 \%
$$

Tabel 8. Klasifikasi Peringkat CAR

\begin{tabular}{ccc}
\hline Urutan & Nilai Komposit & Kategori \\
\hline 1 & CAR $\geq 12 \%$ & Sangat Sehat \\
\hline 2 & $9 \% \leq$ CAR $<12 \%$ & Sehat \\
\hline 3 & $8 \% \leq$ CAR $<9 \%$ & Cukup Sehat \\
\hline 4 & $6 \% \leq$ CAR $<8 \%$ & Kurang Sehat \\
\hline 5 & CAR $\leq 6 \%$ & Tidak Sehat \\
\hline
\end{tabular}

\section{Metode Penelitian}

Dalam mengerjakan penelitian ini penulis menggunakan metode penelitian kuantitatif deskriptif. Hasil penelitian dijabarkan melalui pendekatan deskriptif. Penulis menggunakan jenis data sekunder dalam melakukan penelitian. Teknik pengumpulan data yang dilakukan berupa teknik dokumentasi dimana merupakan teknik pengumpulan data dalam bentuk catatan yang telah terjadi, seperti buku, laporan, dsb. ${ }^{21}$ Data tersebut berupa laporan keuangan PT. Bank Muamalat Indonesia Tbk mulai dari tahun 2016 hingga tahun 2020. Penulis menggunakan teknik analisis data berupa analisis tingkat kesehatan pada Bank Muamalat Indonesia dengan menggunakan metode RGEC yang meliputi beberapa komponen diantaranya Risk Profile (Profil Risiko) dengan perhitungan NPF dan FDR, GCG (Good Corprate Governance) dengan perhitungan PDN, Earnings dengan perhitungan ROA, ROE, NI, dan BOPO, serta komponen Capital dengan indikator perhitungan CAR.

\footnotetext{
${ }^{20}$ Wina Aprilia and Nesti Hapsari, "Pengaruh Tingkat Kesehatan Bank Melalui Metode RGEC Terhadap Nilai Perusahaan (Studi Kasus Pada Perusahaan Perbankan Yang Terdaftar Di Bursa Efek Indonesia Periode 2016-2020)," Neraca Keuangan : Jurnal Ilmiah Akuntansi Dan Keuangan 16, no. 2 (2021): 13, https://doi.org/10.32832/neraca.v16i2.5432.

${ }^{21}$ Sugiyono, Metode Penelitian Pendidikan Pendekatan Kuantitatif, Kualitatif, Dan R\&D (Bandung: Alfabeta, 2013).
} 


\section{Hasil dan Pembahasan}

\section{Risk Profile (Profil Risiko)}

Gambar 1. Bagan hasil penilaian rasio NPF pada Bank Muamalat Indonesia Tahun 2016-2020

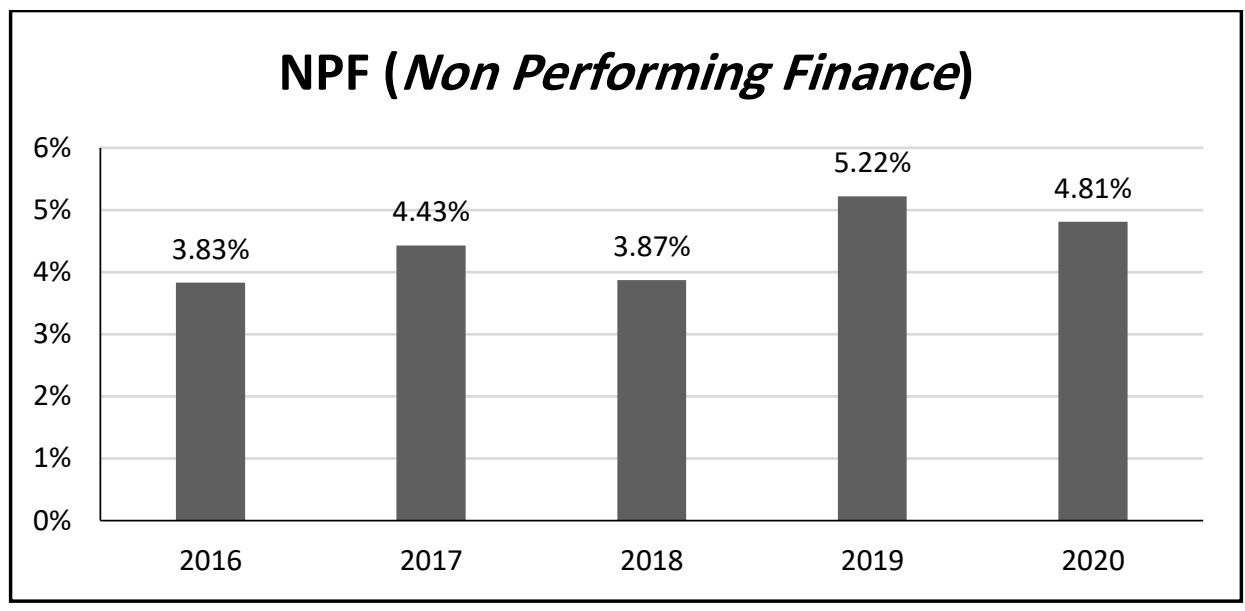

Berdasarkan pada bagan gambar 1 diatas, dapat diketahui bahwa besar rasio NPF Bank Muamalat Indonesia pada tahun 2016 sebesar 3,83\% dan di tahun selanjutnya terjadi sedikit peningkatan sejumlah 0,6\% sehingga pada tahun 2017 rasio NPF bank sebesar 4,43\%. Lalu pada tahun 2018 rasio NPF bank turun menjadi 3,87\%. Selama tahun 2016-2018 rasio NPF Bank Muamalat Indonesia termasuk dalam kategori sehat. Namun, NPF mengalami kenaikan pada tahun 2019 menjadi sebesar $5,22 \%$ yang artinya masuk dalam kategori cukup sehat. Sementara itu, pada tahun 2020 NPF menurun sebanyak 0,41\% sehingga NPF menjadi 4,81\% dan kembali masuk pada kategori sehat.

Gambar 2. Bagan hasil penilaian rasio FDR pada Bank Muamalat Indonesia Tahun 2016-2020

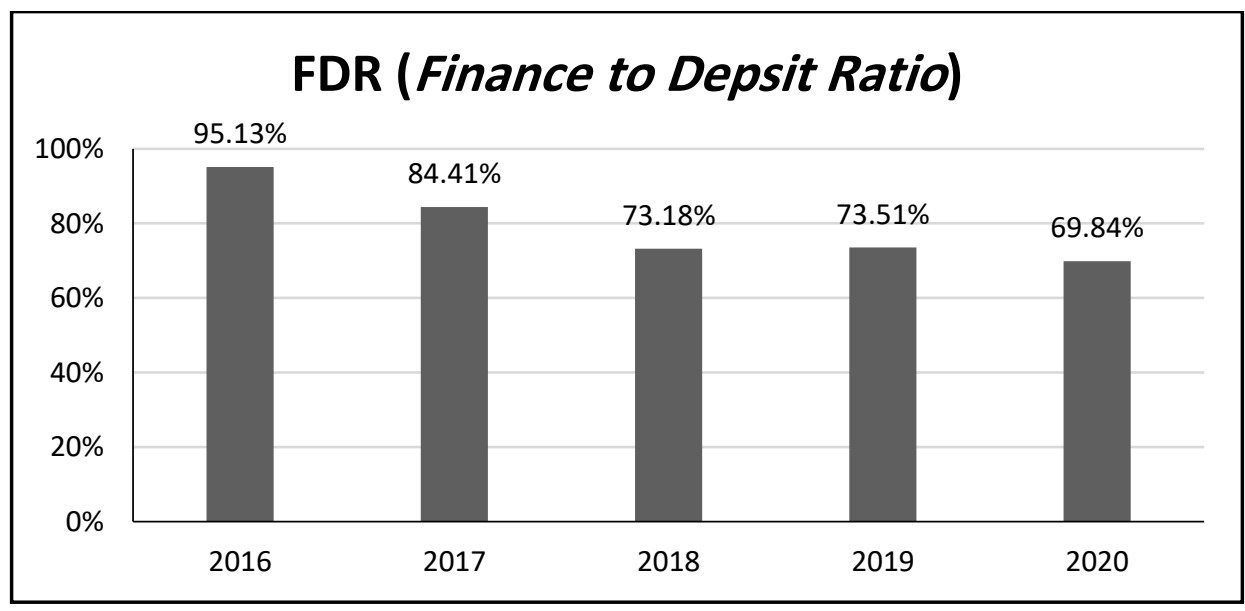

Berdasarkan pada gambar diagram diatas, bisa diketahui bahwa nilai rasio FDR Bank Muamalat Indonesia pada tahun 2016 mencapai 95,13\% yang artinya termasuk pada kategori cukup sehat. Pada tahun selanjutnya, FDR bank menurun 
menjadi $84,41 \%$ dimana ini termasuk ke dalam kategori sehat. Kemudian pada tahun 2018 rasio FDR sebesar 73,18\%, pada tahun 2019 sedikit naik menjadi $73,51 \%$, dan pada tahun 2020 FDR bank menjadi sebesar $69,84 \%$. Selama rentan waktu 2018 hingga 2020 FDR bank terus mengalami penurunan meskipun sempat mengalami sedikit kenaikan di tahun 2019 namun dalam tiga tahun tersebut FDR bank termasuk dalam kategori sangat sehat.

Hasil rasio FDR tahun 2016-2020 ini selaras dengan penelitian yang dilakukan oleh Muhammad Iqbal Surya Pratikto, Clarissa Belinda Fabrela, dan Maziyah Mazza Basya namun menggunakan metode CAMEL yang juga menyatakan bahwa FDR bank untuk tahun 2016-2019 berada dalam rata-rata sehat.

\section{GCG (Good Corporate Governance)}

Gambar 3. Bagan hasil penilaian rasio PDN pada Bank Muamalat Indonesia Tahun 2016-2020

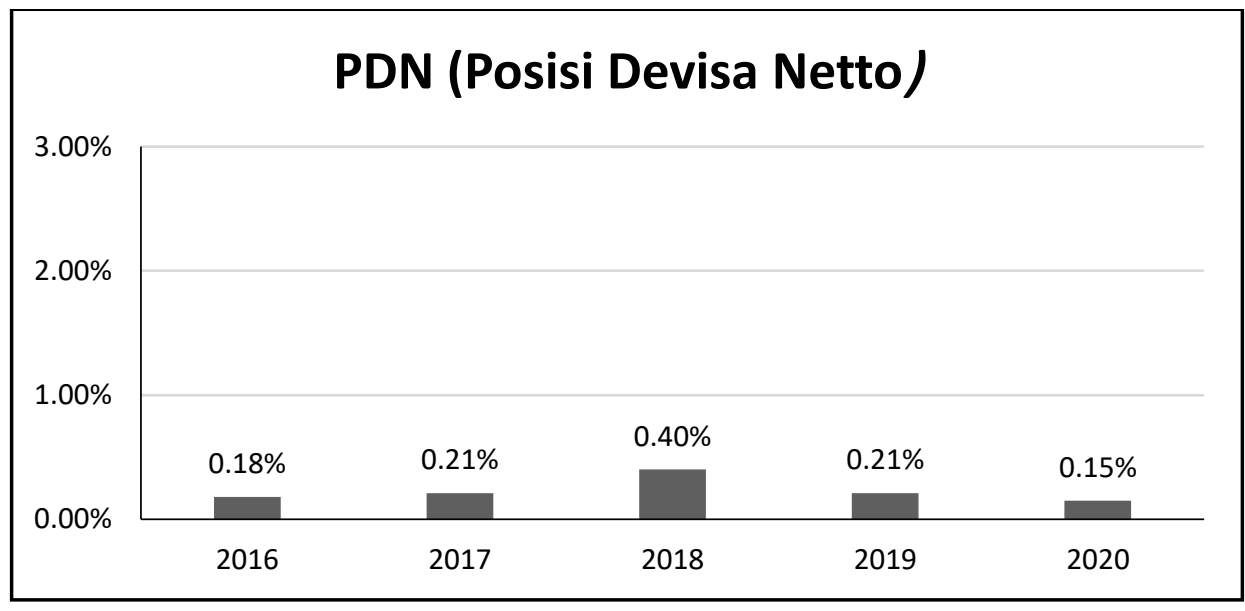

Berdasarkan informasi yang dapat diperoleh melalui gambar 3 tentang bagan hasil penilaian rasio PDN diatas, maka dapat diketahi bahwa besar rasio PDN Bank Muamalat Indonesia pada tahun 2016 adalah 0,18\%, tahun 2017 rasio PDN bank menjadi 0,21\%. Sedangkan untuk tahun 2018 PDN mengalami peningkatan sejumlah 0,19\% sehingga besar PDN di tahun tersebut menjadi 0,40\%. Namun pada tahun 2019 PDN kembali pada posisinya di tahun 2017 yakni menjadi sebesar 0,21\% dan di tahun 2020 PDN senilai 0,15\%. Selama tahun 2016 hingga 2020 menunjukkan bahwa bank tetap memiliki PDN namun nilainya hanya sedikit lebihnya dari $0 \%$ sehingga menunjukkan bahwa pada lima tahun terakhir rasio PDN bank berada dalam kondisi cukup sehat.

Pada penelitian terdahulu yang telah dilakukan oleh Muhammad Iqbal Surya Pratikto, Clarissa Belinda Fabrela, dan Maziyah Mazza Basya dengan metode CAMEL, juga menunjukkan hasil yang sama dan sejalan bahwa rasio PDN pada Bank Muamalat Indonesia selama 2016-2020 PDN masuk dalam kategori cukup sehat. Namun, jika dibandingkan dengan tahun 2013 seperti pada penelitian yang telah dilakukan oleh Zeze Zakaria Hamzah dan Dewi Anggraini dengan metode yang sama yakni RGEC, menunjukkan bahwa di tahun 2013 nilai rasio PDN Bank Muamalat 
Indonesia sempat menduduki kategori yang sangat sehat. Tetapi, di tahun berikutnya PDN terhitung dalam kategori cukup sehat.

\section{Earnings (Rentabilitas)}

Gambar 4. Bagan hasil penilaian rasio ROA pada Bank Muamalat Indonesia Tahun 2016-2020

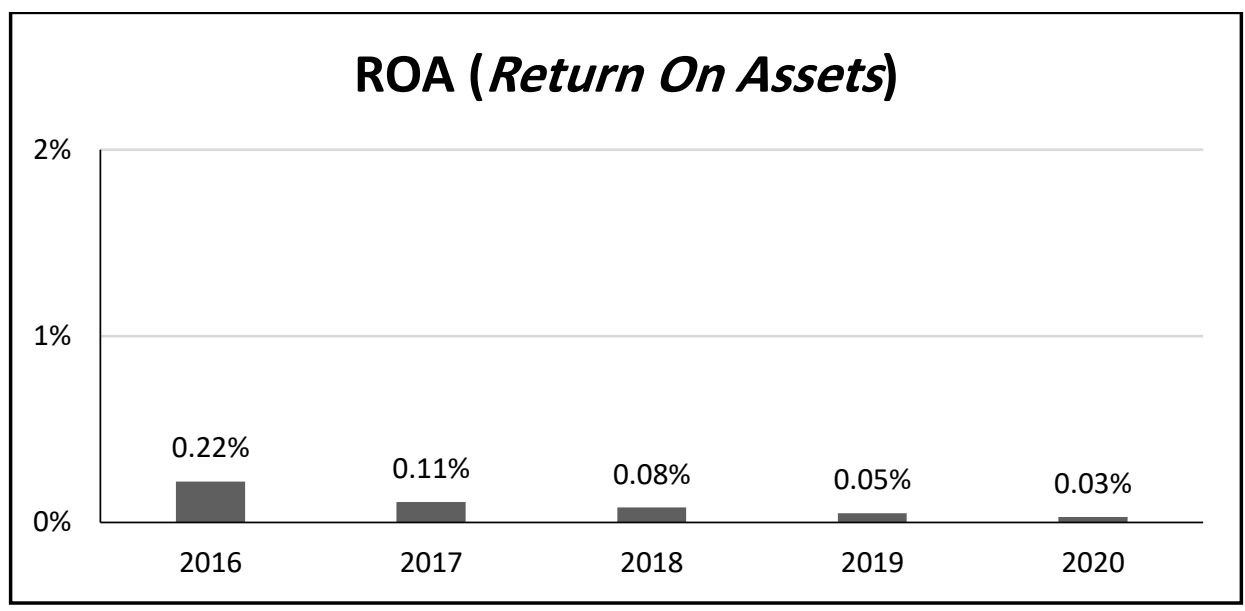

Berdasarkan pada gambar 4 hasil rasio ROA Bank Muamalat Indonesia diatas, dapat diketahui bahwa pada tahun 2016 rasio ROA bernilai sebesar 0,22\%. Hingga tahun 2020 tercatat bahwa rasio ROA pada Bank Muamalat Indonesia terus mengalami penurunan. Rinciannya yakni di tahun 2017, ROA pada bank menyusut setengah nilai dari rasio sebelumnya sehingga pada tahun 2017 ROA sebesar $0,11 \%$. Di tahun 2018 ROA kembali menunjukkan penurunan nilai menjadi sebesar $0,08 \%$ dan pada 2019 sebesar 0,05\%. Serta pada tahun 2020 rasio ROA tercatat sebesar 0,03\%. Melalui tabel klasifikasi peringkat rasio ROA maka dapat diketahui bahwa nilai ROA selama tahun 2016 sampai 2020 berada pada kondisi yang kurang sehat karena nilainya diatas $0 \%$ namun tidak lebih dari $0,5 \%$.

Hasil analisis rasio ROA yang menunjukkan kondisi kurang sehat selama 2016-2020 ini selaras dengan penelitian milik Muhammad lqbal Surya Pratikto, dkk, yang dengan menggunakan metode CAMEL menyatakan jika ROA Bank Muamalat Indonesia berada dalam keadaan kurang sehat selama lima tahun terakhir. 
Gambar 5. Bagan hasil penilaian rasio ROE pada Bank Muamalat Indonesia Tahun 2016-2020

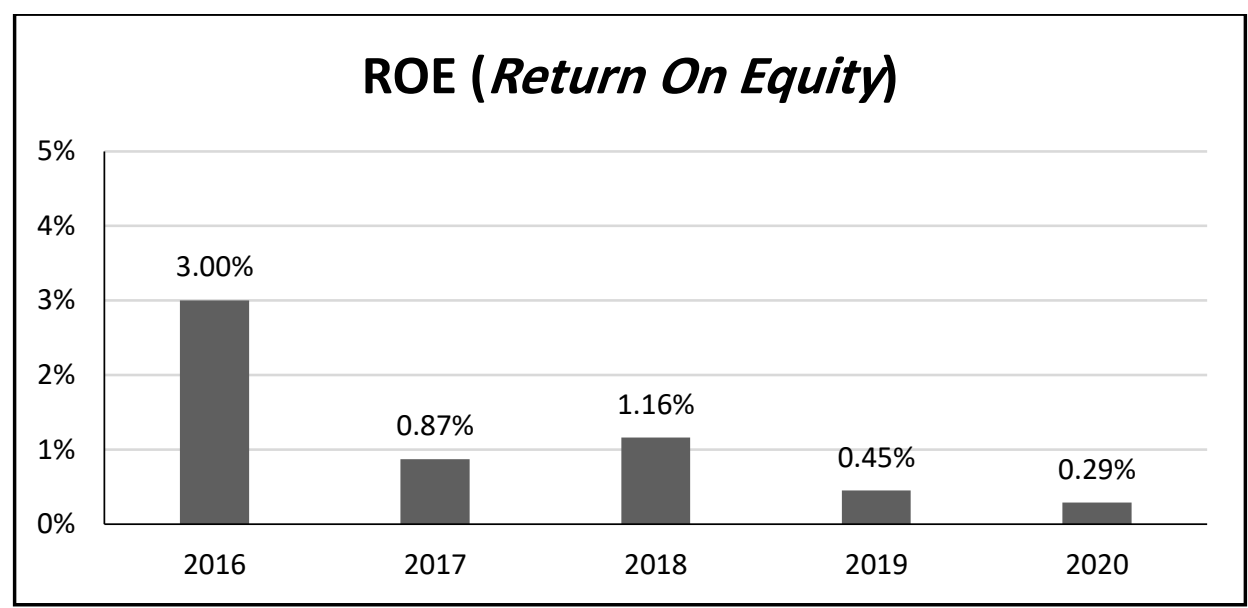

Melihat informasi pada gambar 5 bagan hasil penilaian ROE diatas, dapat diketahui bahwa pada tahun 2016 besar rasio ROE Bank Muamalat Indonesia adalah 3,00\% dimana dari nilai tersebut jelas diketahui bahwa keadaan bank pada rasio $\mathrm{ROE}$ berada di kondisi yang kurang sehat. Di tahun 2017 ternyata bank mengalami penurunan yang cukup tajam pada rasio ROE sebesar 2,13\% sehingga menjadi 0,87\%. ROE mengalami kenaikan kembali di tahun 2018 menjadi 1,16\%. Namun pada tahun 2019 dan 2020 besar rasio ROE terus menurun yakni 0,45\% di tahun 2019 dan 0,29\% di tahun 2020. Hal ini menjelaskan bahwa rasio ROE pada Bank Muamalat Indonesia selama tahun 2016 hingga 2020 berada pada kategori kurang sehat.

Tidak berbeda dengan rasio ROA, hasil analisis ROE-pun juga sejalan dengan penilitian Muhammad lqbal Surya Pratikto, dkk, yang juga menunjukkan kondisi ROE kurang sehat selama beberapa tahun terakhir. Sementara itu, pada penelitian yang telah dilakukan oleh Zeze Zakaria Hamzah dan Dewi Anggraini menunjukkan jika rasio ROE Bank Muamalat Indonesia sempat menduduki kategori cukup sehat di tahun 2013, namun di tahun berikutnya ROE mulai memasuki kategori kurang sehat hingga tahun 2020. 
Gambar 6. Bagan hasil penilaian rasio NI pada Bank Muamalat Indonesia Tahun 2016-2020

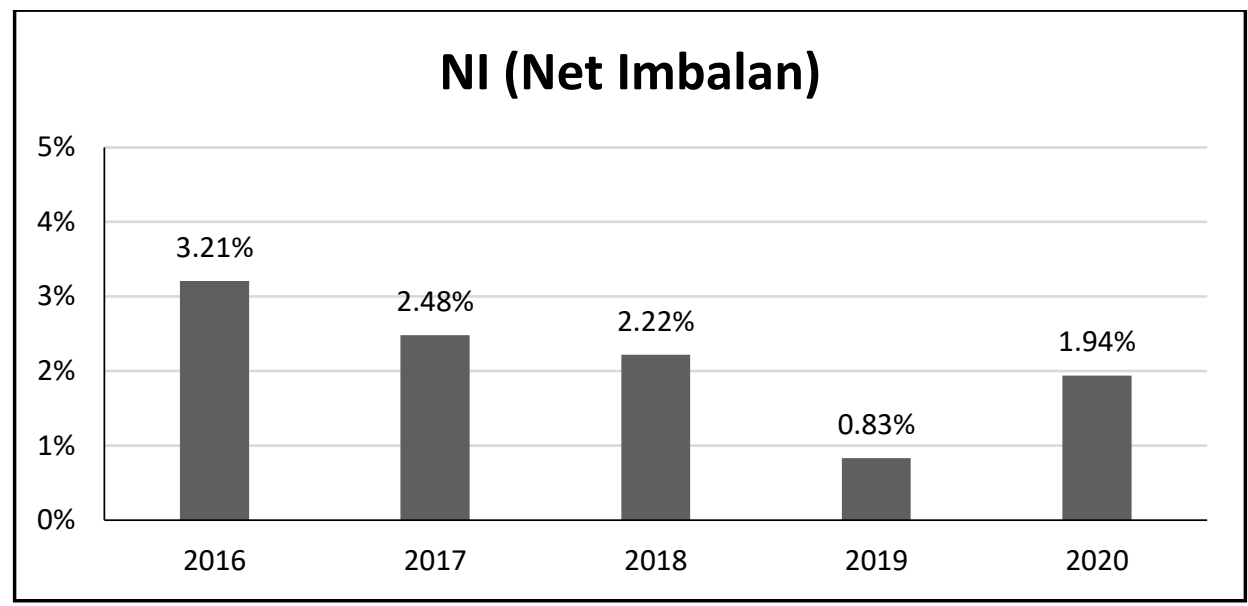

Berdasarkan pada informasi gambar 6 yang menunjukkan diagram hasil penilaian rasio NI pada Bank Muamalat Indonesia diatas, dapat diketahui bahwa pada tahun 2016 besar rasio NI pada bank adalah 3,21\% dimana hal ini menunjukkan jika pada tahun 2016 rasio NI bank berada dalam kategori sehat. Pada tahun 2017, NI mengalami penyusutan nilai menjadi $2,48 \%$ dan di tahun berikutnya $\mathrm{NI}$ berada pada posisi 2,22\% yang artinya pada 2017 dan 2018 kondisi NI masih tergolong dalam kategori sehat. Sementara itu, pada tahun 2019 hasil rasio NI menurun hingga menjadi 0,83\% yang artinya pada tahun $2019 \mathrm{NI}$ termasuk dalam kategori kurang sehat. Dan pada tahun $2020 \mathrm{NI}$ meningkat menjadi 1,94\% sehingga termasuk dalam kategori cukup sehat.

\section{Gambar 7. Bagan hasil penilaian rasio BOPO pada Bank Muamalat Indonesia Tahun} 2016-2020

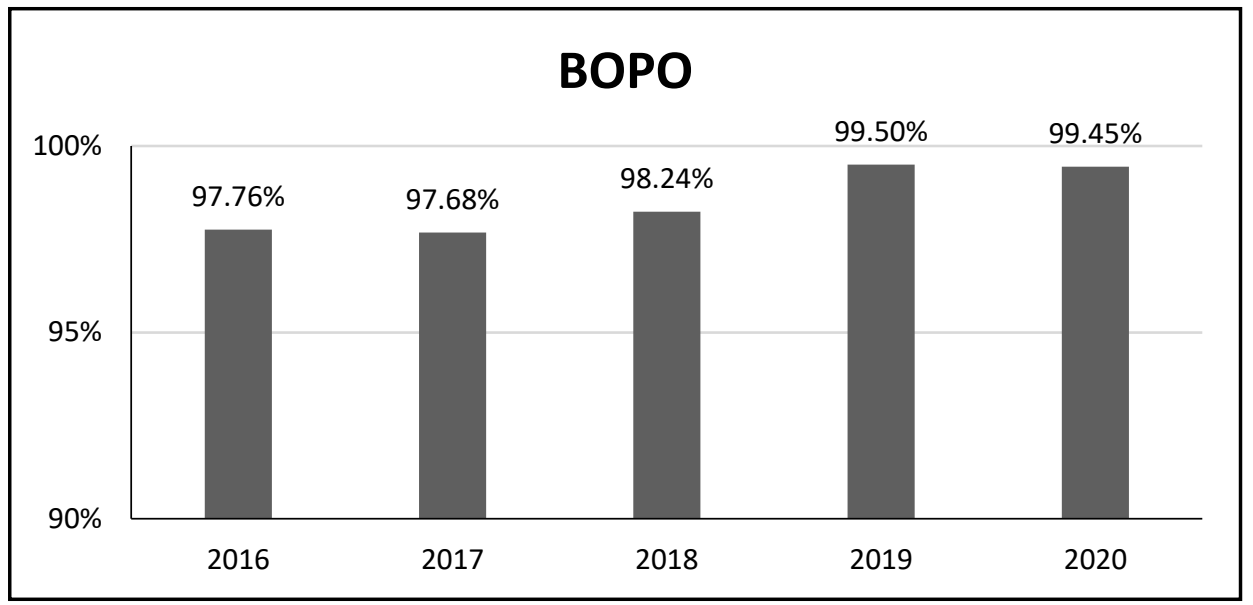

Menurut informasi pada gambar diagram 7 diatas, menunjukkan jika besar BOPO Bank Muamalat Indonesia di tahun 2016 adalah sebesar 97,76\%. Pada tahun selanjutnya rasio BOPO mengalami sedikit penurunan menjadi sebesar $97,68 \%$ dan naik kembali di tahun 2018 menjadi 98,24\%. Pada tahun 2019 rasio BOPO 
meningkat sebesar 1,26\% sehingga menjadi 99,50\% dan menurun 0,05\% pada tahun 2020 menjadi sebesar 99,45\%. Melihat nilai rasio BOPO Bank Muamalat Indonesia pada tahun 2016 hingga 2020 yang selalu berada diatas 97\% maka menunjukkan bahwa rasio BOPO pada bank berada di kategori yang kurang sehat. Hasil ini terbilang sedikit lebih baik dari tahun 2013 hingga 2015 dimana menurut peneitian Zeze Zakaria Hamzah dan Dewi Anggraini, rasio BOPO Bank Muamalat Syariah bahkan pernah mencapai predikat tidak sehat di tahun 2014-2015.

\section{d. CAR (Capital Adequacy Ratio)}

Gambar 8. Bagan hasil penilaian rasio CAR pada Bank Muamalat Indonesia Tahun 2016-2020

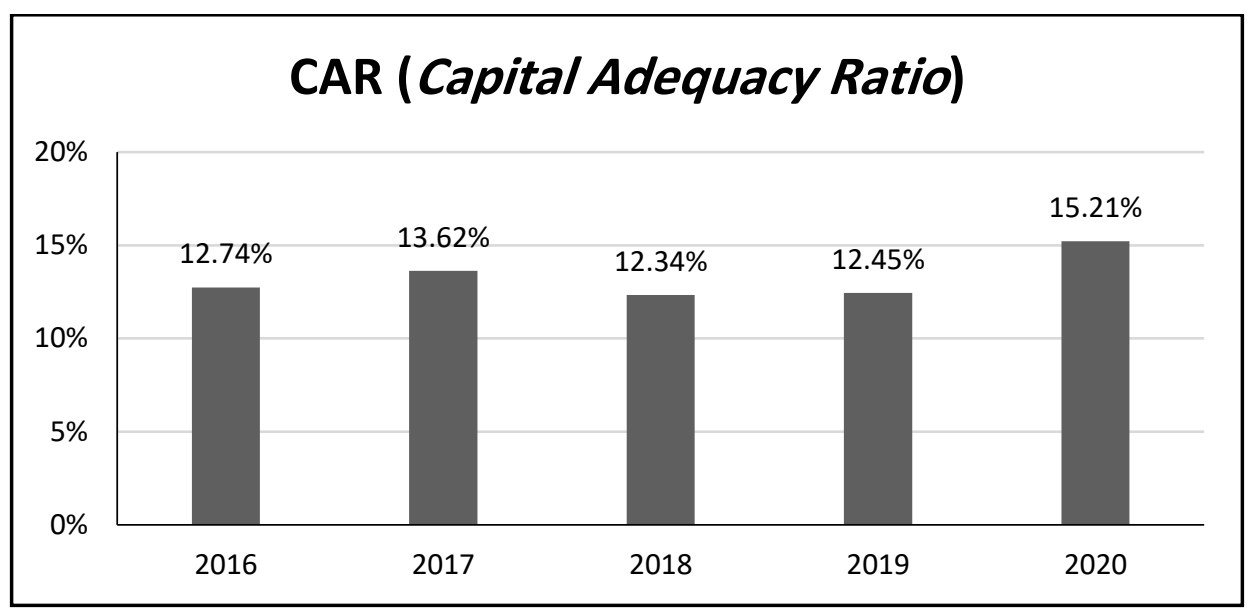

Menurut gambar 8 bagan hasil penilaian rasio CAR diatas, menunjukkan bahwa untuk tahun 2016 rasio CAR pada Bank Muamalat Indonesia sebesar 12,74\% dan sedikit meningkat di tahun berikutnya yakni menjadi $13,62 \%$. Pada tahun 2018, CAR menunjukkan penurunan menjadi sebesar 12,34\% dan sedikit naik di tahun 2019 menjadi 12,45\%. Sementara itu, untuk tahun 2020 hasil rasio CAR mengalami kenaikan hampir $3 \%$ sehingga menjadi $15,21 \%$. Dari hasil rincian rasio CAR diatas, menunjukkan bahwa rasio CAR Bank Muamalat Indonesia di tahun 2016 sampai 2020 terus berada diatas $12 \%$. Hal ini sangat bagus dialami oleh bank karena artinya rasio CAR berada dalam kategori yang sangat sehat selama 5 tahun berturut-turut.

Jika dibandingkan dengan tingkat kesehatan Bank Muamalat Indonesia 3 (tiga) tahun sebelumnya yakni di tahun 2013-2015 yang telah diteliti oleh Zeze Zakaria Hamzah dan Dewi Anggraini dengan metode yang sama pada jurnalnya yang bejudul "Analisis Tingkat Kesehatan Bank Pada PT Bank Muamalat Indonesia Tbk Dengan Menggunakan Metode RGEC (Risk Profile, Good Corporate Governanve, Earnings, \& Capital) Periode 2013-2017", tingkat kesehatan Bank Muamalat Indonesia pada periode 2016-2020 terbilang sedikit lebih baik daripada tiga tahun sebelumnya secara keseluruhan. Namun, merujuk pada penelitian sebelumnya didapatkan fakta bahwa untuk rasio CAR periode 2013-2015 mendapat predikat sangat sehat. Sesuai dengan hasil penelitian kali ini, rasio CAR Bank Muamalat Indonesia juga bertahan dengan predikat sangat sehat di tahun 2016-2020. Artinya, 
bank telah melakukan kinerja yang bagus dalam mempertahankan rasio kecukupan modal dan mengukur sejauh mana risiko kerugian yang akan mereka hadapi.

\section{Penutup}

Berdasarkan dari hasil analisis kesehatan pada Bank Muamalat Indonesia selama tahun 2016-2020, dapat disimpulkan bahwa untuk rasio NPF termasuk dalam kategori sehat kecuali pada tahun 2019 yang masuk dalam kategori cukup sehat. Kemudian untuk rasio FDR tahun 2017-2020, Bank Muamalat Indonesia menduduki posisi sehat. Sedangkan untuk tahun 2016, rasio FDR termasuk di kategori yang cukup sehat.

Pada perhitungan aspek GCG (Good Corporate Governance), rasio PDN bank berada di posisi kategori sehat mulai dari tahun 2016 hingga 2020. Sementara itu, untuk nilai rasio ROA dan ROE bank pada tahun 2016-2020 berada dalam kondisi yang kurang sehat. Sedangkan pada rasio NI, tahun 2016-2018 bank berada dalam kategori sehat, tahun 2019 termasuk dalam kategori kurang sehat, dan di tahun 2020 rasio NI bank masuk pada kategori cukup sehat. Untuk hasil rasio BOPO di tahun 2016-2020 bank mengalami kondisi yang kurang sehat. Sedangkan untuk rasio CAR, bank berada dalam kondisi yang sangat sehat selama tahun 2016 hingga 2020.

Saran yang dapat diambil bagi Bank Muamalat Indonesia yakni diharapkan untuk bisa meningkatkan tingkat kesehatannya terutama pada komponen ROA, ROE, dan BOPO serta mempertahankan tingkat kesehatan yang sudah mencapai kondisi baik, seperti pada rasio CAR supaya sistem operasional bank berjalan dengan semakin baik. Adapun saran untuk peneliti selanjutnya diharapkan untuk dapat memperluas penelitian dengan menambahkan variabel lain didalamnya misalnya pengaruh tingkat kesehatan bank dalam aspek-aspek tertentu supaya dapat diketahui dengan baik kegunaan dan pengaruhnya dalam berbagai hal. Selain itu, juga diharapkan peneliti selanjutnya untuk tidak terpaku pada analisis sektor perbankan saja namun bisa diperluas dengan sektor-sektor perusahaan lain.

\section{DAFTAR PUSTAKA}

Akbar, Rafki Rachmat, and Pandoyo. "Analisis Tingkat Kesehatan Bank Dengan Menggunakan Metode Camel Pada PT. Bank Mualamat Indonesia Tbk." Bisnis Administrasi 5, no. September (2016): 45.

Andrianto, and M. Anang Firmansyah. Manajemen Bank Syariah (Implementasi Teori Dan Praktek). Edited by Qiara Media. CV. Penerbit Qiara Media. CV. Penerbit Qiara Media, 2019.

Anik, Anik, and Suhesti Ningsih. "Analisis Tingkat Kesehatan Bank Mandiri Syariah Dengan Metode Risk Profile, Good Corporate Governace, Earnings and Capital." Jurnal Ilmiah Ekonomi Islam 6, no. 3 (2020): 724. https://doi.org/10.29040/jiei.v6i3.1466.

Aprilia, Wina, and Nesti Hapsari. “Pengaruh Tingkat Kesehatan Bank Melalui Metode 
RGEC Terhadap Nilai Perusahaan (Studi Kasus Pada Perusahaan Perbankan Yang Terdaftar Di Bursa Efek Indonesia Periode 2016-2020)." Neraca Keuangan : Jurnal Ilmiah Akuntansi Dan Keuangan 16, no. 2 (2021): 13. https://doi.org/10.32832/neraca.v16i2.5432.

Ardana, Yudhistira, and W Wulandari. "Tingkat Suku Bunga, Kinerja Keuangan, Dan Bagi Hasil Deposito Pada Perbankan Syariah." Esensi: Jurnal Bisnis Dan Manajemen 8, no. 2 (2018): 177-86. https://doi.org/10.15408/ess.v8i2.8392.

Kasmir. Analisis Laporan Keuangan. Depok: PT. RajaGrafindo Persada, 2019.

Marimin, Agus, and Abdul Haris Romdhoni. "Perkembangan Bank Syariah Di Indonesia." Jurnal Ilmiah Ekonomi Islam 1, no. 02 (2017): 75-87. https://doi.org/10.29040/jiei.v1i02.30.

Mu'minin, Nano Suyatna dan Ayi Mi'razul. "Analisis Tingkat Kesehatan Bank Dan Dampaknya Terhadap Peningkatan Jumlah Nasabah." Jurnal Maps (Manajemen Perbankan Syariah) 5, no. 1 (2021): 40-45.

Nofinawati, Nofinawati. "Perkembangan Perbankan Syariah Di Indonesia." JURIS (Jurnal Ilmiah Syariah) 14, no. 2 (2016): 168. https://doi.org/10.31958/juris.v14i2.305.

Prabowo, Bagya Agung, and Jasri Bin Jamal. "Peranan Dewan Pengawas Syariah Terhadap Praktik Kepatuhan Syariah Dalam Perbankan Syariah Di Indonesia." Jurnal Hukum IUS QUIA IUSTUM 24, no. 1 (2017): 113-29. https://doi.org/10.20885/iustum.vol24.iss1.art6.

Pramana, Agita Putra, and Irni Yunita. "Pengaruh Rasio-Rasio Risk-Based Bank Rating (Rbbr) Terhadap Peringkat Obligasi." Jurnal Manajemen Indonesia 15, no. 1 (2017): 65. https://doi.org/10.25124/jmi.v15i1.394.

Prastyananta, F., M. Saifi, and M. NP. "ANALISIS PENGGUNAAN METODE RGEC (RISK PROFILE, GOOD CORPORATE GOVERNANCE, EARNING, CAPITAL) UNTUK MENGETAHUI TINGKAT KESEHATAN BANK (Studi Pada Bank Umum Yang Terdaftar Di BEI Periode 2012-2014)." Jurnal Administrasi Bisnis S1 Universitas Brawijaya 35, no. 2 (2016): 68-76.

Pratikto, Muhammad Iqbal Surya, and Mohammad Khoiruzi Afiq. "Analisis Tingkat Kesehatan Bank Dan Potensi Financial Distress Menggunakan Metode Rgec Dan Zmijewski Pada Bank Bni Syariah Tahun 2015-2019." Jurnal Ekonomi Syariah Teori Dan Terapan 8, no. 5 (2021): 570. https://doi.org/10.20473/vol8iss20215pp570581.

Pratikto, Muhammad Iqbal Surya, Clarissa Belinda Fabrela, and Maziyah Mazza Basya. "Analisis Kesehatan Laporan Keuangan Pada PT Bank Muamalat Indonesia Tbk Dengan Menggunakan Metode Camel Tahun 2015-2019." OECONOMICUS Journal of Economics 5, no. 2 (2021): 75-85. https://doi.org/10.15642/oje.2021.5.2.75-85.

Pratikto, Muhammmad Iqbal Surya, Ariza Qanita, and Rahma Ulfa Maghfiroh. “Analisis 
Tingkat Kesehatan Dan Potensi Financial Distress Dengan Metode RGEC Pada BNI Syariah Tahun 2014-2018." Jurnal El-Qist 9, no. 1 (2019): 87.

Sari, Nopita. "Analisis Tingkat Kesehatan Bank Dengan Menggunakan Metode Camel Pada PT. BNI Syariah Periode Triwulan Tahun 2015-2017." Islamic Banking: Jurnal Pemikiran Dan Pengembangan Perbankan Syariah 4, no. 1 (2018): 23-32. https://doi.org/10.36908/isbank.v4i1.52.

Shandy Utama, Andrew. "Perkembangan Perbankan Syariah Di Indonesia." UNES Law Review 2, no. 3 (2020): 290-98. https://doi.org/10.31933/unesrev.v2i3.121.

Sugiyono. Metode Penelitian Pendidikan Pendekatan Kuantitatif, Kualitatif, Dan R\&D. Bandung: Alfabeta, 2013.

Wahasusmiah, Rolia, and Khoiriyyah Rahma Watie. "Metode RGEC : Penilaian Tingkat Kesehatan." I-Finance 04, no. 02 (2018): 170-84.

Zakaria Hamzah, Zeze, and Dewi Anggraini. "ANALISIS TINGKAT KESEHATAN BANK PADA PT BANK MUAMALAT INDONESIA, TbK DENGAN MENGGUNAKAN METODE RGEC (RISK PROFILE, GOOD CORPORATE GOVERNANCE, EARNING \& CAPITAL) PERIODE 2013 - 2017." Economicus 13, no. 1 (2020): 46-56. https://doi.org/10.47860/economicus.v13i1.164. 